\title{
Cadmium determination in Lentinus edodes mushroom species
}

\author{
Determinação de cádmio em cogumelos da espécie Lentinus edodes
}

\author{
Vera Akiko MAIHARA ${ }^{1 *}$, Patricia Landim da Costa MOURA ${ }^{1}$, Marília Gabriela Miranda CATHARINO ${ }^{1}$,

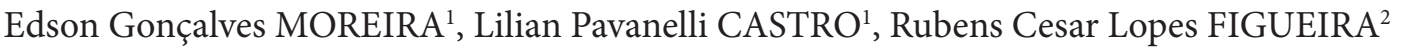

\begin{abstract}
Many studies have drawn attention to the occurrence and concentration of toxic elements found in the fruiting body of mushrooms. Some edible mushroom species are known to accumulate high levels of inorganic contaminants, mainly cadmium, mercury, and lead. There are about 2,000 known edible mushroom species, but only 25 of them are cultivated and used as food. In Brazil, the most marketed and consumed mushroom species are Agaricus bisporus, known as Paris champignon, Lentinus edodes, or Shitake and Pleurotus sp, also called Shimeji or Hiratake. In this study, the concentration of cadmium was determined in Lentinus edodes mushrooms from different cities in São Paulo state and some samples imported from Japan and China. The analyses were performed by graphite furnace atomic absorption spectrometry after $\mathrm{HNO}_{3}-\mathrm{H}_{2} \mathrm{O}_{2}$ digestion. The results showed a lower concentration of Cd in the mushrooms cultivated in São Paulo (0.0079 to 0.023 mg.kg-1 in natura) than that of the mushrooms cultivated abroad ( 0.125 to $0.212 \mathrm{mg} \cdot \mathrm{kg}^{-1}$ in natura). Although there is no tolerance limit for Cd in mushrooms in Brazil, the results show that Lentinus edodes mushrooms can be safely consumed.
\end{abstract}

Keywords: cadmium; mushrooms; Lentinus edodes; atomic absorption spectrometry.

\begin{abstract}
Resumo
Muitos estudos têm encontrado elementos tóxicos em cogumelos. Sabe-se que algumas espécies de cogumelos comestíveis acumulam elevados níveis de contaminantes inorgânicos, como cádmio, mercúrio e chumbo. Há cerca de duas mil espécies de cogumelos comestíveis, mas apenas 25 espécies são cultivadas e usadas como alimentos. No Brasil, as espécies mais comercializadas e consumidas são Agaricus bisporus, conhecida como Champignon de Paris; Lentinus edodes ou Shitake, e Pleurotus sp, também chamada de Shimeji ou Hiratake. Neste trabalho, o cádmio (Cd) foi determinado em amostras de cogumelos da espécie Lentinus edodes cultivadas em diversas cidades do Estado de São Paulo e algumas amostras importadas do Japão e da China. O cádmio foi determinado por espectrometria de absorção atômica com forno de grafite após digestão com a mistura de $\mathrm{HNO}_{3}$ conc. e $\mathrm{H}_{2} \mathrm{O}_{2} 30 \%$. As amostras analisadas foram cultivadas em São Paulo e importadas de dois países. Os resultados mostraram concentrações de Cd menores nos cogumelos cultivados no Estado de São Paulo ( 0.0079 a 0.023 mg. $\mathrm{kg}^{-1}$ in natura $)$ do que nas amostras importadas ( 0.212 a $0.125 \mathrm{mg} \cdot \mathrm{kg}^{-1}$ in natura). Apesar de não existirem limites máximos de tolerância para Cd em cogumelos na legislação brasileira, os resultados mostraram que os cogumelos da espécie Lentinus edodes podem ser consumidos com segurança.

Palavras-chave: cádmio; cogumelos; espécie Lentinus edodes; espectrometria de absorção atômica.
\end{abstract}

\section{Introduction}

Man's relationship with mushrooms is both ancient and fascinating. The Egyptians believed that mushrooms were a gift from the god Osiris, while the ancient Romans called them a "divine food" because they thought that mushrooms were the result of lightning thrown down to earth by Jupiter during storms (MANZI et al., 1999). Mushrooms are traditionally consumed because of their agreeable taste and pleasant aroma.

Mushrooms are also excellent nutritional sources since they provide proteins, fibers, vitamins, and minerals such as K, $\mathrm{P}$, and Fe. The mineral composition of mushrooms, however, may also contain some toxic elements such as $\mathrm{As}, \mathrm{Cd}$, and $\mathrm{Hg}$ (VETTER, 2004).

Many studies have drawn attention to the occurrence and concentration of toxic elements found in the fruiting body of mushrooms. Edible mushroom species are known to accumulate high levels of inorganic contaminants, mainly $\mathrm{Cd}, \mathrm{Hg}$, and $\mathrm{Pb}$ (COCCHI et al., 2006; SVOBODA; HAVL`ČKOVÁ; KALAČ, 2006). High Cd levels have been found in mushrooms collected in several regions in Europe, mainly in silver-mining areas, where a $149 \mathrm{mg} \cdot \mathrm{kg}^{-1}$ average content of Cd was determined (dry weight basis) in the species Agaricus sivaticus.

In several countries, studies have revealed high toxic element concentrations in various mushroom species, especially in European countries where mushroom consumption is high and where families include mushroom cultivation as a domestic activity (KALAČ; SVOBODA, 2000; JANSSON; KUTTI, 2004).

In Brazil, mushroom consumption is still low (about $30 \mathrm{~g}$ per year per capita) compared with other countries such as France where consumption is nearly $2 \mathrm{~kg}$ per year per capita and Germany, where consumption is $4 \mathrm{~kg}$ per year per capita.

Instituto de Pesquisas Energéticas e Nucleares IPEN, Comissão Nacional de Energia Nuclear - CNEN-SP, Av. Professor Lineu Prestes, 2242, CP 11049, Butantã, CEP 05508-000, São Paulo, SP, Brasil, e-mail: vmaihara@ipen.br

2 Instituto Oceanográfico, Universidade de São Paulo - USP, Praça do Oceanográfico, 191, CEP 05508-120, São Paulo, SP, Brasil

${ }^{*}$ Corresponding author 
However, consumption is growing due to mushrooms' refined flavor and nutritional and medicinal values. From 1995 to 2005 , the world's mushroom production increased more than $60 \%$. In the last years, Brazilian mushroom production and commercialization has increased considerably as well (BONONI et al., 1999).

About 2,000 edible mushroom species are mentioned in the literature. Of these, only 25 species are cultivated and used as food. Only 10 are currently commercialized (URBEN et al., 2001).

The first mushroom species cultivated in Brazil was Agaricus bisporus (Paris champignon). Other species also cultivated are Pleurotus sp (Shimeji and Hiratake) and Lentinus edodes (Shitake) (BONINI et al., 1999).

Lentinus edodes is the oldest edible mushroom species known, and presently it is the second most consumed in the world. Japan is the main producer of this species. Several medicinal aspects can be found in the literature due to their biologically active compounds. Chang and Miles (1989) described antiviral and antitumor effects in the soluble extract of this mushroom.

Mushrooms are cultivated in substrates such as tree trunks, wood logs, straw, sawdust, berry of cane, corn cobs, cotton seed, and cocoa seed hulls or gypsum. Therefore, mushroom cultivation allows for the recycling of several agricultural and agro-industrial waste products (TSHINYANGU, 1996). In Brazil, the L. edodes species is cultivated in tree trunks such as chestnut, oak, eucalyptus, or elm trees. Mogi das Cruzes is the main region in Brazil where edible mushrooms are cultivated, and the production is about seven kilograms of fresh mushrooms for each $100 \mathrm{~g}$ of humid substrate (BONONI et al., 1999).

Among inorganic contaminants, cadmium is of public health interest due to its high toxicity after accumulating in multiple organs in the human body. Cadmium is a relatively rare element that is released to the air, land, and water by human activities. In general, the two major sources of contamination are the production and utilization of cadmium and the disposal of wastes containing cadmium. Increase in soil cadmium content will result in the uptake of cadmium by plants. Edible free-living food organisms such as shellfish, crustaceans, and fungi are naturally susceptible to increase in soil cadmium. Mushrooms, in particular, may be very rich in cadmium (SOYLAK et al., 2005; SESLI, 2006).

In general, toxic elements are present in food samples at low concentrations; therefore, sensitive analytical techniques are desirable, such as Graphite Furnace Atomic Absorption Spectrometry (GF AAS). This is a suitable and widely used technique for determining trace elements due to its high selectivity, sensitivity, and ability to directly determine several analytes in different samples (AMORIM FILHO et al., 2006).

There has been very little research done with mushrooms especially in regard to toxic element concentration levels in Brazil. Maihara et al. (2008) determined As and Cd content in 20 samples of three species of edible mushrooms (Agaricus bisporus, Pleurotus ostreatus and Lentinula edodes) produced and consumed in the State of São Paulo. It was observed that As and $\mathrm{Cd}$ concentrations differed widely among the mushroom species, and the Lentinula edodes presented high Cd levels (0.114 to 0.119 mg. $\mathrm{kg}^{-1}$ in dry weight). A study performed by Mattila et al. (2001) showed that $L$. edodes is an effective Cd accumulator (0.100 mg. $\mathrm{kg}^{-1}$ in dry weight).

In the present study, Graphite Furnace Atomic Absorption Spectrometry was applied to determine the cadmium content in fresh Lentinus edodes samples produced in São Paulo State and in dehydrated samples from abroad (China and Japan), which are available for consumption in retail markets in São Paulo city. The objective was to verify if the national Lentinus edodes production and imported samples are safe for consumption, considering the maximum limit levels for contaminants in foods.

\section{Materials and methods}

\subsection{Mushroom Samples}

Six fresh Lentinus edodes mushroom samples were purchased from retail stores and directly from producers of various cities in São Paulo state from 2006 to 2007. The samples were purchased in packs of $400 \mathrm{~g}$ each. Eight dehydrated samples of Lentinus edodes of different brands, imported from Japan and China, were purchased from retails stores in 2009.

\subsection{Sample preparation}

The fresh mushroom samples were cleaned and submerged for 10 minutes in high-purity water (resistivity 18.2 $\mathrm{M} \Omega . \mathrm{cm}$ - Millipore Corporation, Milford, MA, USA). Next, they were cut into small pieces with a plastic knife, put on Petri plates or plastic recipients, and frozen for 24 hours. The samples were then freeze-dried for 10 to 15 hours in a ModulyD Model freeze-dryer (Thermo Electron Corporation, Milford, MA, USA). After the freeze-drying process, the samples were ground and homogenized using a domestic blender with Ti blades. These mushroom samples were then stored in pre-cleaned polyethylene bottles.

The dehydrated samples were cut, ground, homogenized using a domestic blender, and then stored in pre-cleaned polyethylene bottles until analysis.

\subsection{Graphite Furnace Atomic Absorption Spectrometry (GF AAS)}

The GF AAS Cd determination was performed according to Semmler (2007). Approximately $0.30 \mathrm{~g}$ of dried mushroom samples was taken for analysis. Four milliliters of concentrated nitric acid (Merck, Darmstadt, Germany) and one $\mathrm{mL}$ of hidrogen peroxide $30 \%$ (Merck) were added to the sample in a PFA (perfluoralcoxi) vessel (Savillex Corporation, Minnetonka, MN, USA), closed, and left overnight at room temperature. Then, the samples were digested in a digestion block (Tecnal Equip. Lab, Piracicaba, SP, Brazil) for 3 hours at $90^{\circ} \mathrm{C}$. The digested samples were allowed to cool to room temperature and were diluted with high-purity water up to $25 \mathrm{~mL}$. The blanks were analyzed in the same manner as the samples. 
A Perkin Elmer AAnalyst 800 atomic absorption spectrometer (Perkin Elmer, Vernon Hills, Illinois, USA) with Zeeman background correction at a wavelength of $228.8 \mathrm{~nm}$ for cadmium was used. An EDL Cadmium lamp was used in the experiments. The optimized heating program used for measurements of cadmium is shown in Table 1 .

A Spex certified standard solution of Cadmium (1000 $\left.\pm 3 \mathrm{mg} \cdot \mathrm{L}^{-1}\right)$ was diluted accordingly to obtain a $7.0 \mathrm{ng} \cdot \mathrm{mL}^{-1}$ stock solution. This solution was further diluted by the AS- 800 autosampler for construction of a Cd calibration curve of: 1.38; 4.17; and $6.90 \mathrm{ng} \cdot \mathrm{mL}^{-1}$. The calibration curve coefficients were obtained by a linear regression fit with least-squares method performed by the spectrometer software.

$20 \mu \mathrm{L}$ aliquots of the sample solution and $10 \mu \mathrm{L}$ of matrix modifier $\left(\mathrm{NH}_{4} \mathrm{H}_{2} \mathrm{PO}_{4} 0.5 \%(\mathrm{~m} / \mathrm{v})\right.$ and $\left.\mathrm{Mg}\left(\mathrm{NO}_{3}\right)_{2} 0.03 \%(\mathrm{~m} / \mathrm{v})\right)$ were introduced to the furnace tube by the autosampler. After the atomization step, the $\mathrm{Cd}$ concentration was calculated by the spectrometer software after two replicate measurements.

Blank background levels were below the detection limit. The analyses were carried out in duplicate with differences between the measurements of up to $10 \%$. The limit detection for cadmium was determined using the IUPAC criterion (CURRIE, 1995), and the values obtained were $0.007 \mathrm{mg} . \mathrm{kg}^{-1}$ for the GF AAS method used.

\subsection{Certified reference materials}

The accuracy of the GF AAS method was verified by analysis of certified reference materials. The reference materials Bovine Liver (SRM 1577b), from the National Institute of Standards and Technology (NIST- Gaithersburg, MD, USA), and Mixed Polish Herbs (MPH-2), from the Institute of Nuclear Chemistry and Technology (INCT- Warszawa, Poland) were used for Cd determination.

\section{Results and discussion}

The reference materials were used for quality control purposes and to evaluate the effectiveness of the method applied. The accuracy of the method was also evaluated via participation in a proficiency test organized by the International Atomic Energy Agency under IAEA INT/1/054, project "Preparation of reference materials and organization of proficiency test rounds", for the certification of a mushroom reference material (POLKOWSKA-MOTRENKO; ROSSBACH, 2007).

The z-score values were calculated using the Horwitz function (INTERNATIONAL..., 2002). In all reference materials analyzed, the $\mathrm{z}$-score values were $\leq 2$ showing that the results were considered satisfactory in the $95 \%$ confidence interval of the certified values, as presented in Table 2.

The Cd concentrations in Lentinus edodes mushrooms were determined on a dry weight basis and are shown in Table 3. The cadmium concentration varied from 0.102 (SPS) to 0.207 (CSS) mg. $\mathrm{kg}^{-1}$ for the mushrooms produced in São Paulo and from 0.212 (CKI) to 1.25 (CSD) $\mathrm{mg} \cdot \mathrm{kg}^{-1}$ for the imported mushrooms.
The mushroom samples cultivated in São Paulo presented Cd levels lower than those of the imported samples of the same species of mushroom. However, one of them (CKI from China) presented levels $\left(0.212 \mathrm{mg} \cdot \mathrm{kg}^{-1}\right)$ close to those of the national samples. The $\mathrm{Cd}$ concentrations determined in these samples can be considered low since according to Svoboda, Havlǐčková and Kalač (2006) Cd content varying between 0.10 to $0.21 \mathrm{mg}$. $\mathrm{kg}^{-1}$ (dry weight basis) in mushrooms can be considered low.

Cadmium levels of mushroom samples (dry weight basis) have been reported in the range of $1.2-2.2 \mathrm{mg} \cdot \mathrm{kg}^{-1}$ (COLAK et al., 2007), 0.14-0.95 mg.kg-1 (SOYLAK et al., 2005), and $0.25-2.75 \mathrm{mg} \cdot \mathrm{kg}^{-1}$ (SESLI, 2006). In general, the Cd values determined in edible mushroom samples commercialized in São Paulo were similar to the literature values.

The application of statistic ANOVA at 95\% confidence level indicated a significant difference among the three places of origin: São Paulo, Japan, and China $\left(\mathrm{F}=10.63\right.$ and $\left.\mathrm{F}_{\text {crit }}=3.98\right)$, while the comparison between Japan and China showed no significant difference $\left(\mathrm{F}=0.11\right.$ and $\left.\mathrm{F}_{\text {crit }}=5.99\right)$. The results indicated that Cd content in L. edodes produced in São Paulo have less $\mathrm{Cd}$ than the imported samples.

According to the literature, several factors are responsible for the different Cd levels in the same mushroom species, such as local soil conditions, substrate used for cultivation, and pollution from various sources (SVOBODA; HAVLǏČKOVÁ; KALAČ, 2006), which may be related to the difference observed in the $\mathrm{Cd}$ content in the Brazilian and imported mushroom samples.

To obtain the Cd concentration in mushroom samples in natura, the obtained values in dry weight basis were converted considering the water content in L. edodes, which was approximately $90 \%$, as assessed in this study.

Hence, the Cd level in the analyzed L. edodes in natura varied from 0.0079 (SML) to 0.125 (CSD) $\mathrm{mg} \cdot \mathrm{kg}^{-1}$. Brazilian legislation sets the value of $1.0 \mathrm{mg} \cdot \mathrm{kg}^{-1}$ (in natura) only for fish and fish products (BRASIL, 1998). The European Union Community Regulation (EC) establishes maximum limits

Table 1. Graphite furnace program for determination of Cd.

\begin{tabular}{lccc}
\hline \multicolumn{1}{c}{ Step } & Temperature $\left({ }^{\circ} \mathrm{C}\right)$ & $\begin{array}{c}\text { Time }(\mathrm{s}) \\
(\mathrm{ramp}, \mathrm{hold})\end{array}$ & $\begin{array}{c}\text { Argon flow } \\
(\mathrm{mL} / \mathrm{minute})\end{array}$ \\
\hline Drying & 110 & 1.30 & 250 \\
Ashing & 130 & 15.30 & 250 \\
Pyrolysis & 500 & 10.20 & 250 \\
Atomization & 1500 & 0.5 & 0 \\
Cleaning & 2450 & 1.3 & 250 \\
\hline
\end{tabular}

Table 2. Cd determination in the Reference Materials in mg.kg-1.

\begin{tabular}{lccc}
\hline \multicolumn{4}{c}{ Cadmium Concentration in reference materials $\left(\mathrm{mg}^{-k^{-1}}\right)$} \\
\hline Reference Material & $\mathrm{x} \pm \mathrm{s}^{\mathrm{a}}$ & Certified Value & $\mathrm{z}$-score \\
\hline Bovine Liver & $0.53 \pm 0.01$ & $0.50 \pm 0.03^{\mathrm{b}}$ & 1.0 \\
Mixed Polish Herb & $0.221 \pm 0.006$ & $0.199 \pm 0.015^{\mathrm{c}}$ & 1.5 \\
IAEA Mushroom & $2.29 \pm 0.29$ & $2.48 \pm 0.27^{\mathrm{c}}$ & -0.69 \\
\hline
\end{tabular}

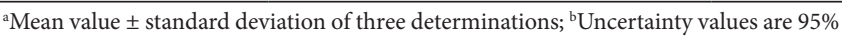
confidence interval; ' Uncertainty values are expanded uncertainties $(k=2)$. 
Table 3. Cadmium determination in Lentinus edodes samples.

\begin{tabular}{|c|c|c|c|c|}
\hline \multirow{2}{*}{$\begin{array}{c}\text { Type of } \\
\text { mushroom }\end{array}$} & \multirow{2}{*}{$\begin{array}{c}\text { Sample } \\
\text { identification }\end{array}$} & \multirow{2}{*}{$\begin{array}{l}\text { Origin of the } \\
\text { samples }\end{array}$} & \multicolumn{2}{|c|}{ 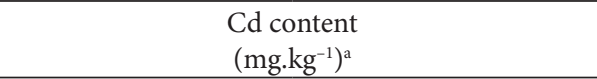 } \\
\hline & & & dry weight & in natura ${ }^{\mathrm{b}}$ \\
\hline Fresh & SML & Mogi das Cruzes city & $0.118 \pm 0.016$ & $0.0079 \pm 0.0006$ \\
\hline Fresh & SPS & Suzano city & $0.102 \pm 0.015$ & $0.0093 \pm 0.0008$ \\
\hline Fresh & SMM & Mirandópolis city & $0.118 \pm 0.010$ & $0.013 \pm 0.001$ \\
\hline Fresh & SJL & Juquitiba city & $0.171 \pm 0.011$ & $0.019 \pm 0.001$ \\
\hline Fresh & CSS & São Paulo city & $0.207 \pm 0.015$ & $0.023 \pm 0.003$ \\
\hline Fresh & CSP & São Paulo city & $0.176 \pm 0.010$ & $0.020 \pm 0.007$ \\
\hline Dehydrated & JBI & Japan & $0.670 \pm 0.064$ & $0.067 \pm 0.006$ \\
\hline Dehydrated & JII & Japan & $0.996 \pm 0.053$ & $0.100 \pm 0.005$ \\
\hline Dehydrated & CJD & Japan & $0.797 \pm 0.010$ & $0.080 \pm 0.006$ \\
\hline Dehydrated & CSD & China & $1.25 \pm 0.06$ & $0.125 \pm 0.006$ \\
\hline Dehydrated & CGI & China & $0.969 \pm 0.013$ & $0.097 \pm 0.001$ \\
\hline Dehydrated & CKI & China & $0.212 \pm 0.002$ & $0.0212 \pm 0.0002$ \\
\hline Dehydrated & CCI & China & $0.707 \pm 0.017$ & $0.071 \pm 0.002$ \\
\hline Dehydrated & CRI & China & $0.553 \pm 0.006$ & $0.0555 \pm 0.0006$ \\
\hline
\end{tabular}

${ }^{\mathrm{a}}$ Mean value \pm standard deviation $(\mathrm{n}=2)$; ${ }^{\mathrm{b}}$ for dehydrated samples, in natura content was estimated considering a $90 \%$ water content.

for Cd in cultivated mushrooms of $0.20 \mathrm{mg} \cdot \mathrm{kg}^{-1}$ wet weight (EUROPEAN..., 2006).

\section{Conclusions}

From the data obtained in this study, the consumption of L. edodes mushroom in Brazil can be considered safe since the $\mathrm{Cd}$ contents determined in the Brazilian and imported samples were low considering the $\mathrm{Cd}$ maximum limits for foodstuffs.

Since data on Cd in mushrooms are scarce in this country, this study can serve as the starting point for further studies on mushrooms taking into account factors that can contribute to the presence of toxic elements in mushrooms, such as substrate, as well as the environment where the mushrooms are cultivated.

\section{Acknowledgements}

The authors are grateful for the financial support provided by Fapesp and CNPq.

\section{References}

AMORIM FILHO, V. R. et al. Simultaneous determination of Cd and $\mathrm{Pb}$ in antibiotics used in sugar-cane fermentation process by GFAAS. Ecletica Química, v. 31, n. 2, p. 7-12, 2006. http://dx.doi. org/10.1590/S0100-46702006000200001

BONONI, V. L. et al. Cultivo de cogumelos comestíveis. São Paulo: Íconi, 1999.

BRASIL. Portaria n 685, de 27 de agosto de 1998. Regulamento Técnico princípios gerais para o estabelecimento de níveis máximos de contaminantes químicos em alimentos. Diário Oficial da República Federativa do Brasil, Brasília, DF, 24 set. 1998. Seção 1, p. 3.

CHANG, S. T.; MILES, P. G. Edible mushrooms and their cultivation. Boca Raton: CRC Press, 1989.

COCCHI, L. et al. Heavy metals in edible mushrooms in Italy. Food Chemistry, v. 98, p. 277-284, 2006. http://dx.doi.org/10.1016/j. foodchem.2005.05.068
COLAK, A. et al. Biochemical composition of some Turkish fungi. Asian Journal of Chemistry, v. 19, p. 2193-2199, 2007.

CURRIE, L. A. Nomenclature in evaluation of analytical methods including detection and quantification capabilities (IUPAC recommendations 1995). Pure \& Applied Chemistry, v. 67, p. 1669-1723, 1995. http://dx.doi.org/10.1351/pac199567101699

EUROPEAN COMISSION REGULATION. Setting maximum levels for certain contaminants in foodstuffs. Official Journal of the European Union, 2006. Disponível em: <http://eur-lex.europa.eu/ en/index.htm>. Acesso em: 20 mar. 2012

JANSSON, L. M.; KUTTI, L. Micronutrients in edible mushrooms. Human Nutrition, v. 5, p. 1-8, 2004.

INTERNATIONAL ORGANIZATION FOR STANDARDIZATION - ISO. ISO/DIS 13528: Statistical methods for use in proficiency testing by interlaboratory comparisons. ISO, 2002. $66 \mathrm{p}$.

KALAČ, P.; SVOBODA, L. A review of trace element concentrations in edible mushrooms. Food Chemistry, v. 69, p. 273-281, 2000.

MAIHARA, V. A. et al. Arsenic and cadmium content in edible mushrooms from São Paulo, Brazil determined by INAA and GF AAS. Journal of Radioanalytical Nuclear Chemistry, v. 278, n. 2, p. 395-397, 2008. http://dx.doi.org/10.1007/s10967-008-0807-3

MANZI, P. et al. Nutrients in edible mushrooms: an inter-species comparative study. Food Chemistry, v. 65, p. 477-482, 1999. http:// dx.doi.org/10.1016/S0308-8146(98)00212-X

MATTILA, P. et al. Contents of vitamins, mineral elements, and some phenolic compounds in cultivated mushrooms. Journal Agricultural and Food Chemistry, v. 49, p. 2343-2348, 2001. PMid:11368601. http://dx.doi.org/10.1021/jf001525d

POLKOWSKA-MOTRENKO, H.; ROSSBACH, M. Preparation and characterization of a proficiency test material "Polish mushrooms" supported by the International Atomic Energy (IAEA), Vienna. Accreditation Quality Assurance, v. 12, p. 343-350, 2007. http:// dx.doi.org/10.1007/s00769-007-0293-2

SEMMLER, M. G. M. C. Biomonitoração de Hg, Cd, Pb e outros elementos em áreas costeiras do estado de São Pulo por meio do mexilhão transportado Perna perna (Linnaues 1758). 2007. 140 f. Tese (Doutorado)-Instituto de Pesquisas Energéticas e Nucleares, Universidade de São Paulo, São Paulo, 2007. 
SESLI, E. E. Trace element contents of some selected fungi in the ecosystem of Turkey. Fresenius Environmental Bulletin, v. 15, p. 518-522, 2006.

SOYLAK, M. et al. Determination of trace metals in mushroom samples from Kayseri, Turkey. Food Chemistry, v. 92, p. 649- 652, 2005. http://dx.doi.org/10.1016/j.foodchem.2004.08.032

SVOBODA, L.; HAVLǏČKOVÁ, B.; KALAČ, P. Contents of cadmium, mercury and lead in edible mushrooms growing in a historical silver-mining area. Food Chemistry, v. 96, p. 580-585, 2006. http:// dx.doi.org/10.1016/j.foodchem.2005.03.012
TSHINYANGU, K. K. Effect of grass hay substrate on nutritional value of Pleurotus ostreatus var. columbinus. Nahrung, v. 40, n. 2, p. 79-83, 1996. http://dx.doi.org/10.1002/food.19960400207

URBEN, A. F. et al. Mushrooms production by means of modified Chinese technology. Brasília: Embrapa, 2001. 151 p.

VETTER, J. Arsenic content of some edible mushroom species. European Food Research and Technology, v. 219, p. 71-74, 2004. http://dx.doi.org/10.1007/s00217-004-0905-6 